\title{
Postcards from the edge (of the Arabian Sea). Tales from the ballPark: this liminal life
}

\author{
Di Ball \\ mail@theballpark.com.au
}

\begin{abstract}
so binDi set off to India and attempted to peel back the veils. But India was not always kind to her, the photo shoot beauty a mere layer. She was older now, a young mind trapped in the body of a 60 year old. It was difficult. She visited forts and palaces, and wished they were not all built on the top of hills. She experienced the stillness of a lake at sunset, quickly marred by the din of traffic. She wasnt looking for God, and never found her....But she found her vioce again in Kerala where her heart sang. Her smile returned. Her laughter was heard.
\end{abstract}

Artists statement from

(binDi Ball is deeply superficial: 2012)

Re-Picturing the Feminine: New Hybrid Realities in the Artworld A Survey of Indian and Australian Contemporary Female Artists

Art brought me to this place, but art and so much more sees my returning and living here 6 months of every year. For 6 years. This PLACE is Fort Cochin in the state of Kerala in South India. The Art that brought me here was my participation in an exhibition enitled Re-Picturing the Feminine: New Hybrid Realities in the Artworld - A Survey of Indian and Australian Contemporary Female Artists at OED Gallery Fort Cochin, running concurrently with the first contemporary art Biennale in India: the Kochi-Muziris Biennale 20I2. I had decided to spend 6 weeks in Fort Cochin in order to make new work informed by the place, but I had never been to India so I went on a tour in North India beforehand. I spent 23 days travelling from Mumbai to New Delhi via Mt Abu, Udapair, Jodhpur, Jaipur, Jailsalmer, Agra, Orchha and Varanasi and arrived in the south exhausted and not a fan. I can't eat spicy food, I don't like crowds, and the rubbish everywhere was horrible. I may have exclaimed; “I am such a Paris girl!!”. Yet here I am, 6 years later, living a liminal life; on the edge of the Arabian Sea, between East and West, between 2 cultures, navigating my way.

Fort Cochin is essentially a village within a larger metropolis called Ernakulam. It sits at the mouth of the Periyar River overlooking a major shipping channel which sees container ships, naval vessels, gargantuan cruise ships, and fishing boats both big and small ply the waters. (Best seen from a table at Seagulls with a cold Kingfisher beer in hand.) Kerala's motto id God's Own Country and Fort Cochin and its adjacent town of Mattancherry are home to I 3 different cultures/ religions. It is also famous for spices and India's first contemporary art Biennale. 


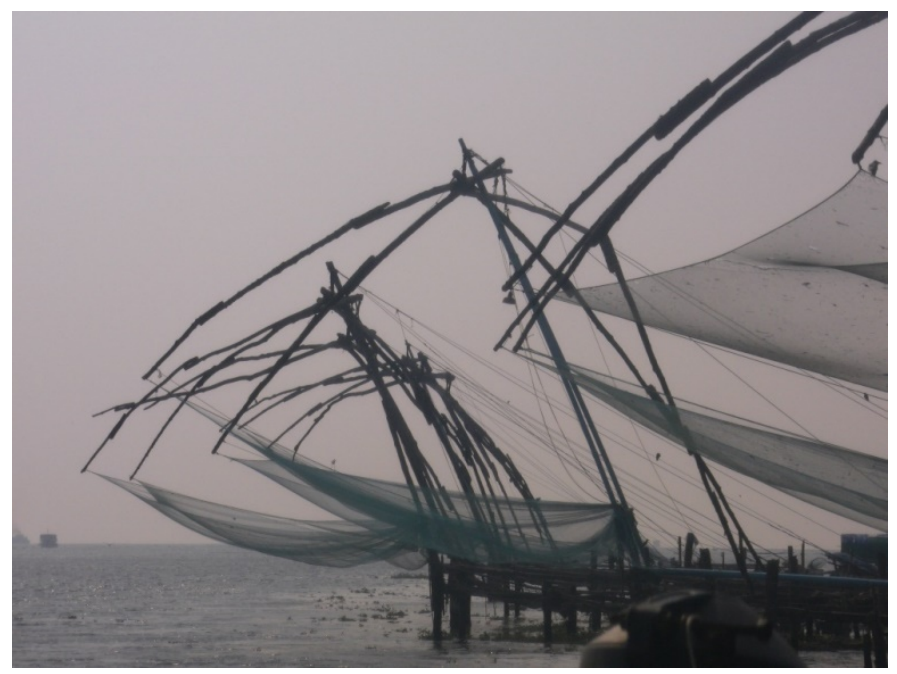

Chinese fishing nets, Fort Cochin.

The first Biennale was called the Kochi-Muziris Biennale because it wished to reintroduce the name of Muziris.

The Kochi Muziris Bennale seeks to create a new language of cosmopolitanism and modernity that is rooted in the lived and living experience of this old trading port, which for more than six centuries, has been a crucible of numerous communal identities. (...) These (...) pre-date the post-enlightenment ideas of cultural pluralism, globalization and multiculturism. They can be traced to Muziris, the ancient city that was buried under layers of mud and mythology after a massive flood in the I $4^{\text {th }}$ century. I

The story of Muziris starts from early 3000 BC when Babylonians, Assyrians and Egyptians and later Arabs and Phoenicians came to the Malabar Coast in search of spices; Muziris in Kodungallur entered into the cartography of World trade map.

Tamil Sangam literature (300BC to 300AD) describes Roman ships coming to Muziris laden with gold to be exchanged for pepper, turning Muziris into the hub of a major spice trade. Evidence from a papyrus in the Vienna museum speaks of trade agreement between Muziris and Alexandria indicating that a substantial amount of trade flourished between India and the Greco Roman world that passed through Muziris.

With its streets, its houses, its covered fishing boats, where they sell fish, where they pile up rice-with the shifting and mingling crowd of a boisterous river-bank were the sacks of pepper are heaped up-with its gold deliveries, carried by the ocean-going ships and brought to the river bank by local boats, the city of the gold-collared Kuttuvan (Chera chief), the city that bestows wealth to its visitors indiscriminately, and the merchants of the mountains, and the merchants of the sea, the city where liquor abounds, yes, this Muciri, were the rumbling ocean roars, is given to me like a marvel, a treasure?

\footnotetext{
I Against All Odds (2012), DCBooks, p. 20.

${ }^{2}$ The Purananuru is a Tamil poetic work in the Ettuthokai, one of the eighteen melkanakku noolgal. It is a treatise on kingship: what a king should be, how he should act, how he should treat his subjects and how he should show his generosity. The Purananuru is one of the eight books in the secular anthology of Sangam literature and is entirely unique in Indian literature, which are nearly all religious texts during this era. The Purananuru is a source of information on the political and social history of prehistoric Tamil Nadu.
} 
Pliny the Elder gives a description of voyages to India in the Ist century AD. He refers to many Indian ports in his The Natural History (which became a model for later encyclopedias and scholarly works).

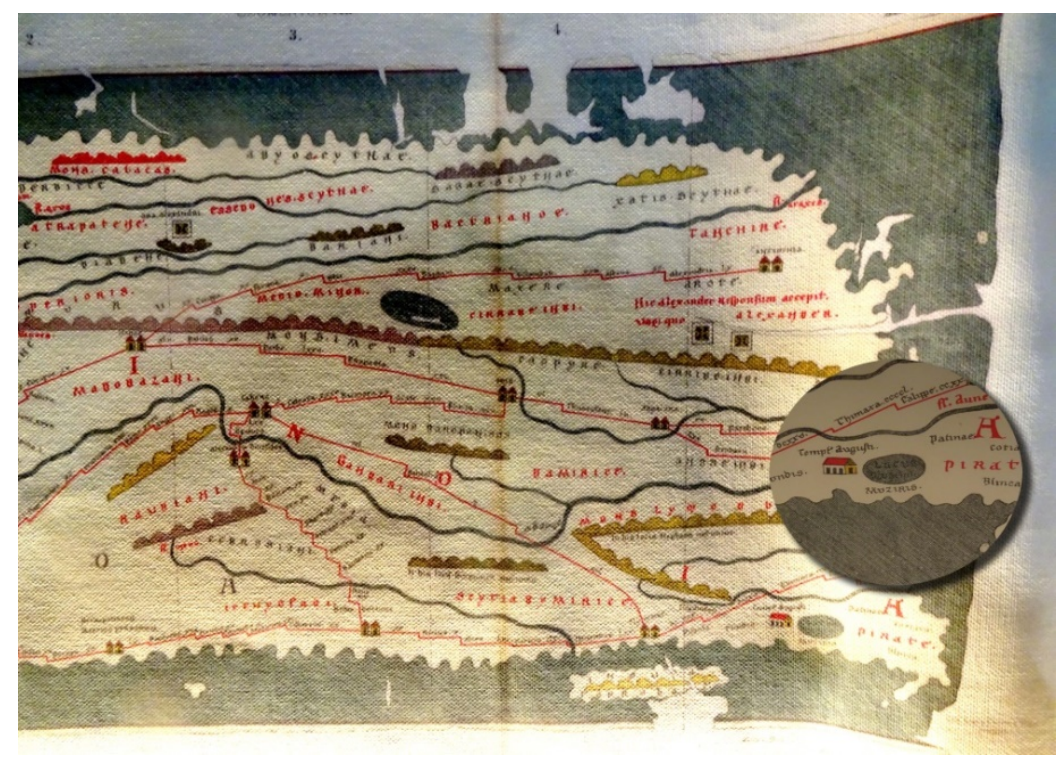

The Table Peitingeriana is one of the oldest maps of the world depicting ancient towns, seas, rivers, forests, mountain ranges and Roman Roads. It dates to the $12^{\text {th }}$ century AD but is a copy of a $4^{\text {th }}$ century Roman map. Comprising II sheets of parchment it measures $6800 \mathrm{~mm}$ long and is $330 \mathrm{~mm}$ wide making it a compressed rendering of the real landscape. Muziris is in the bottom left of this copy in the Muziris Museum in Pattanam.

To those who are bound for India, Ocelis in the Red Sea is the best place for embarkation. If the wind, called Hippalus (south-west Monsoon), happens to be blowing it is possible to arrive in forty days at the nearest market in India, Muziris by name. This, however, is not a very desirable place for disembarkation, on account of the pirates which frequent its vicinity, where they occupy a place called Nitrias; nor, in fact, is it very rich in articles of merchandise. Besides, the roadstead for shipping is a considerable distance from the shore, and the cargoes have to be conveyed in boats, either for loading or discharging. At the moment that I am writing these pages, the name of the King of this place is Celebothras.

The current port of Kochi was first formed in I34I AD when there was a tsunami -like disaster following which the river Periyar flooded its banks altering the geography and burying the ancient port of Muziris. And so, on the 12/I2/2012, the Kochi-Muziris Biennale opened to great success in the area known as Fort Cochin/Mattancherry in the larger area of Kochi. Bose Krishnamachari, the biennale's cofounder, attributes this (success) to the city's history and cultural profile. 


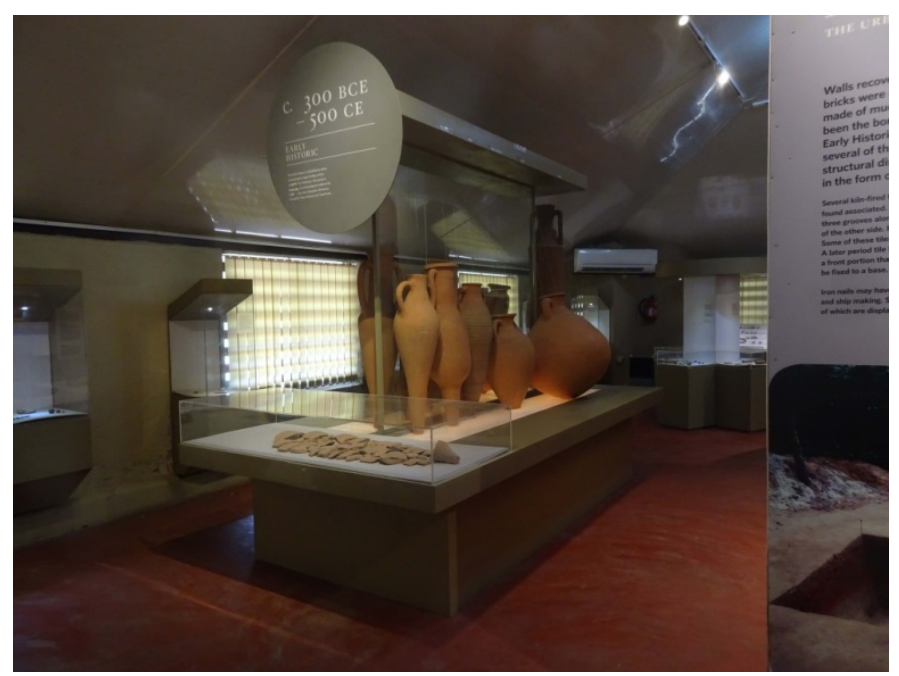

Muziris Children's Museum, Pattanam, Kerala

Kerala Council for Historical Research

Kochi and Muziris represent a long tradition of open interaction with the rest of the world, a vibrant exchange of ideas with the Chinese, Portuguese, Dutch, French and English traders. This has left an indelible mark on the city's culture, cuisine and architecture, offering perspectives from all corners of the globe and different time periods. ${ }^{3}$

The book serving as a record of this first Biennale is titled Against All Odds. It charts the stormy waters leaning up to the opening day, providing an insight into the vision, the politics, the negative campaigns, but ultimately, its' great success. There was nothing to start with - no infrastructure, only a town with some disused colonial warehouses and bungalows. And a vision. A vision to create India's first Art Biennale to transform contemporary art in the country. This vision was a result of an idea by Kerala born artists Bose Krishnamachari and Riyas Komu who had left to further their artistic careers but had always hoped to return. In the Preface to the book, Bose describes those times:

“(....) We had no idea that (the Biennale) would sweep over us like an avalanche. Indeed it has hurt and caused more damage than an avalanche could. (...) It was easier dreamt and discussed than done, It had virtually thrown us into a cauldron. It was a journey not to be forgotten: painful testing, and above all, memorable. The path was strewn with hurdles and troubles but never did we think of calling it quits." 4

And it was a great success.

Curated by Bose and Riyas, featuring 94 artists from 23 countries across 14 venues, the multicoloured flag rose up the pole in the historic compound of Aspinwall House on $12 / 12 / 2012 .^{5}$

\footnotetext{
${ }^{3}$ https://economictimes.indiatimes.com/magazines/travel/rediscovering-the-ancient-port-city-ofmuziris/articleshow $/ 57226035 . \mathrm{cms}$ ?utm_source=contentofinterest\&utm_medium=text\&utm_campaign=cppst ${ }^{4}$ Against All Odds (20I2), DCBooks, p. 10.

${ }^{5}$ Aspinwall House is a large sea-facing heritage property in Fort Kochi on the way to Mattancherry. The property was originally the business premises of Aspinwall \& Company Ltd. established in 1867 by English trader John H Aspinwall. Under the guidance of Aspinwall the Company traded in coconut oil, pepper, timber, lemon grass oil, ginger, turmeric, spices, hides and later in coir, coffee, tea and rubber.
} 


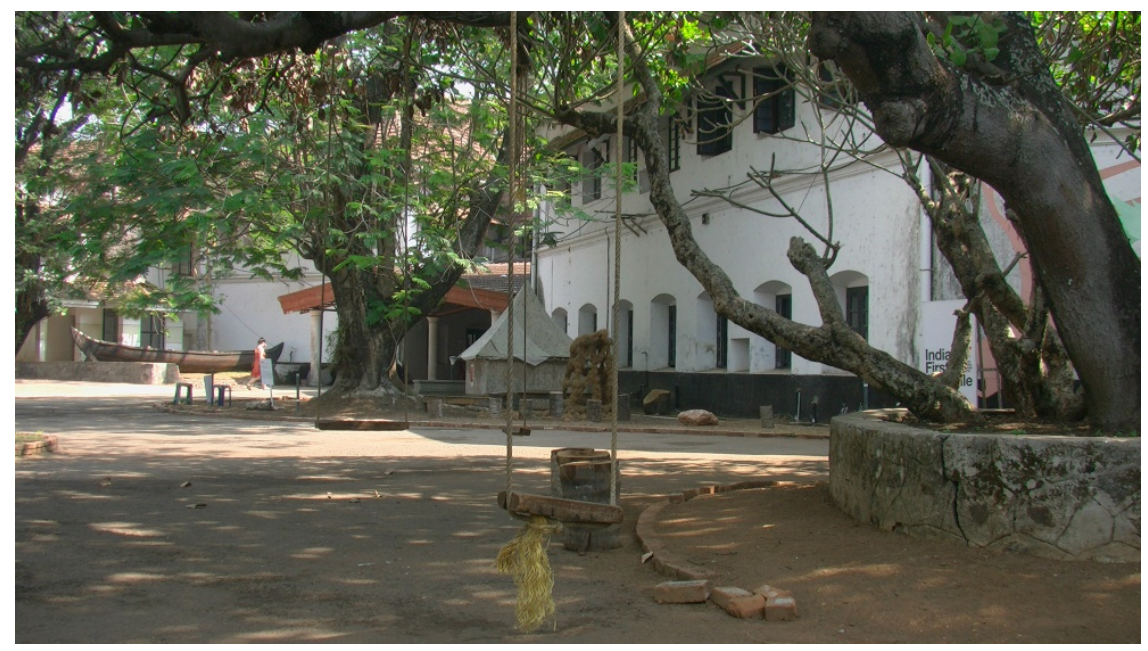

Aspinwall House.

It became the world's first biennale to be archived and digitized by Google Art Project. The Google Art Project has archived the entire Biennale and is open to anyone with an internet connection ${ }^{6}$.

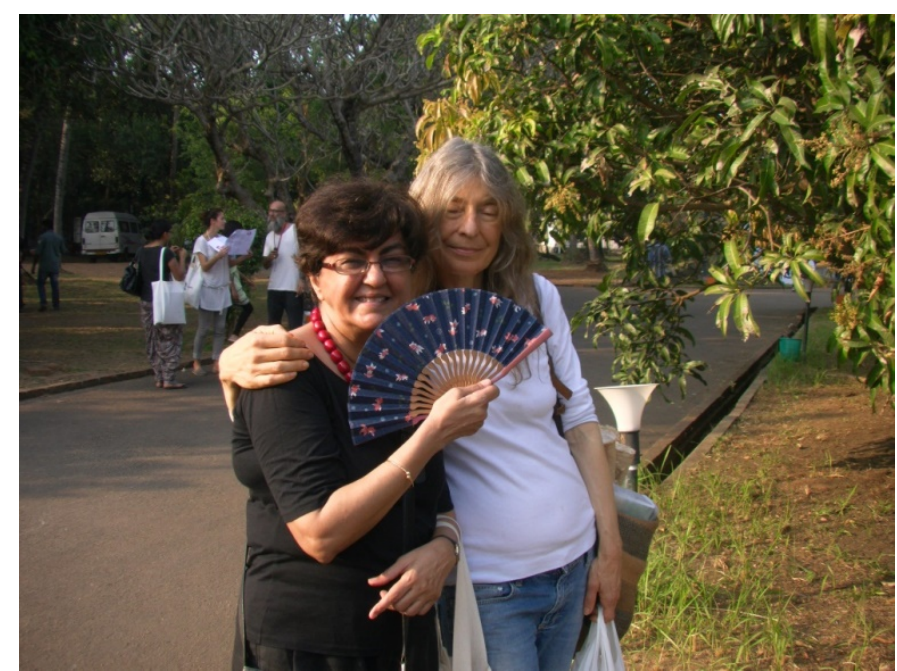

Nalini Malani and Fiona Hall, artists extraordinaire.

It presented 'Site Imaginaries', a two-day symposium co-organised by Marieke Van Hal (Biennial Foundation) and advised by Gayatri Sinha and Paul Domela (Liverpool Biennial) ${ }^{7}$.

The Biennale actively engages the rich domain of cosmopolitanism and modernity that is rooted in the lived and living experience of this old trading port, which, for more than six centuries, has been a crucible of numerous communal identities.

It is necessary to explore and retrieve memories in the current global context to posit alternatives to political and cultural discourses, and build a platform for dialogue for a new aesthetics and politics rooted in the Indian experience.

\footnotetext{
${ }^{6}$ https://artsandculture.google.com/partner/kochi-biennale

7 https://www.facebook.com/KochiMuzirisBiennale/posts/534220259935I 58
} 
From a global perspective we also need to examine the artist as manifest in expanding geographies, and a redefinition of the regions of art. The two-day international symposium to coincide with the first Kochi-Muziris Biennale will discuss these issues pertinent to the biennale8.

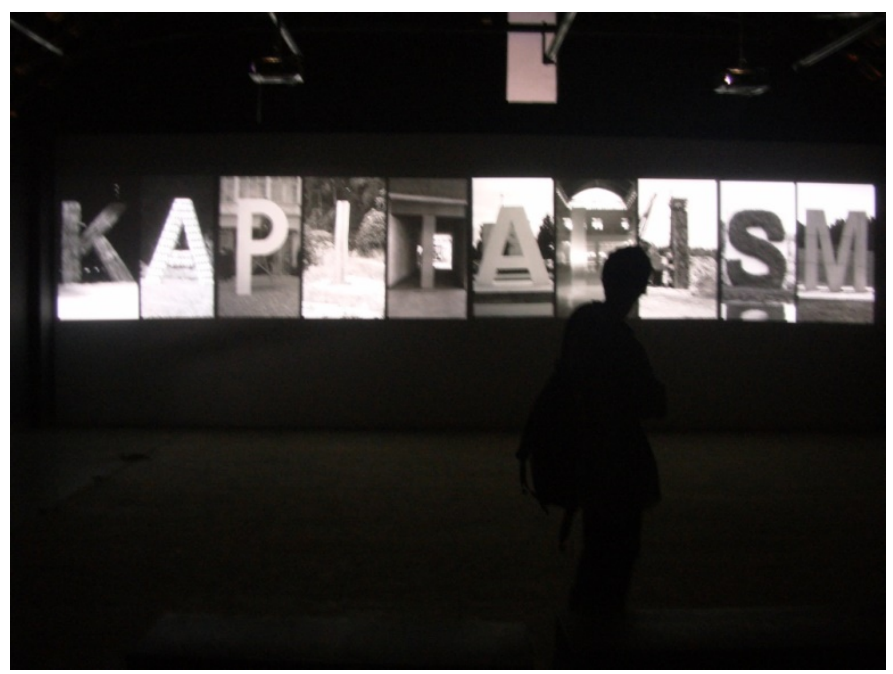

Santiago Sierra (2012) Destroyed Word (installation view of video)

It presented “Let's Talk”; a series of lectures. It revitalized Durbar Hall'. Its' educational outreach programmes gave 50 students from II colleges a chance to be a part of India's first Biennale and interact with some of the best contemporary artists from across the globe. It revived traditional art forms.

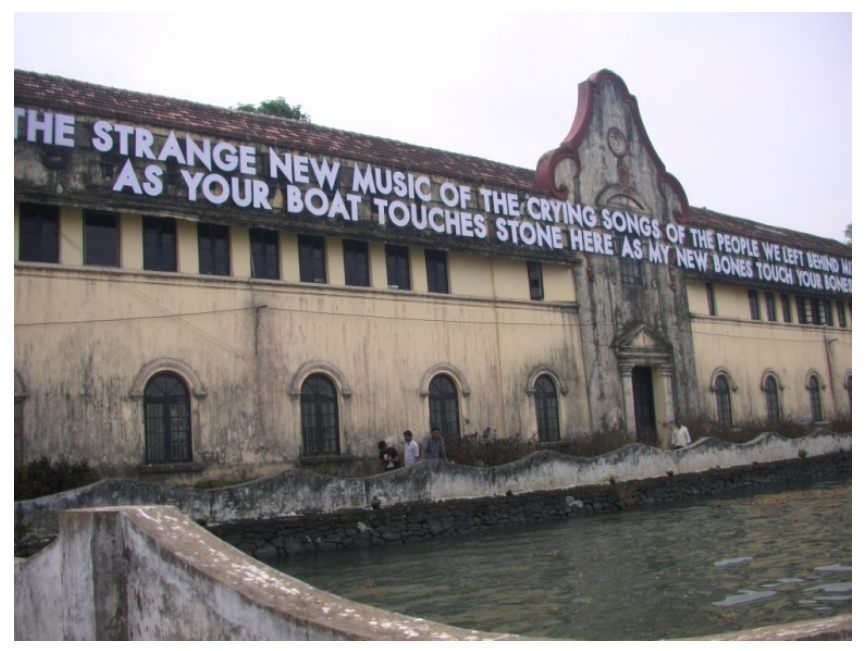

On the left. Robert Montgomery (2012) Fado Music in Reverse.

And in doing so it changed Fort Cochin/Mattancherry. Locals referred to it as OUR Biennale; indeed the very word Biennale inserted itself into the lexicon. There were

\footnotetext{
${ }^{8}$ http://www.biennialfoundation.org/biennials/kochi-muziris-biennale-india/

${ }^{9}$ Durbar Hall was a heritage structure in Ernakulam City which was transformed into a world class exhibition space by the Kochi Biennale Foundation as one of their first projects. The work was carefully completed without affecting the heritage status of the building.
}

I I 4 | The Journal of Public Space, 3(I), 20I8 | ISSN 2206-9658

City Space Architecture / Queensland University of Technology / UN-Habitat 
300,000 visitors in that first year and this grew to 500,000 in 2014 and even more in 2016. Biennales have proliferated globally often as a means to "use" culture as an economic driver resulting in a global mobility of artists, curators, gallerists, critics, collectors and visitors on an international level that brings with it the potential for urban regeneration and economic dispersion. In Fort Cochin/Mattancherry this benefit was obvious to homestay owners, restaurants, tea shops, postcard sellers, rickshaw drivers . Local people stepped up, on an individual level, realising what the biennale was doing for them, socio-economically and culturally, and in terms of putting Kochi on the international culture map. The Biennale venues were opened up to the public using public spaces, or allowing access to venues from which the public is usually excluded, and in so doing created a sense of the use of space "out of the ordinary".
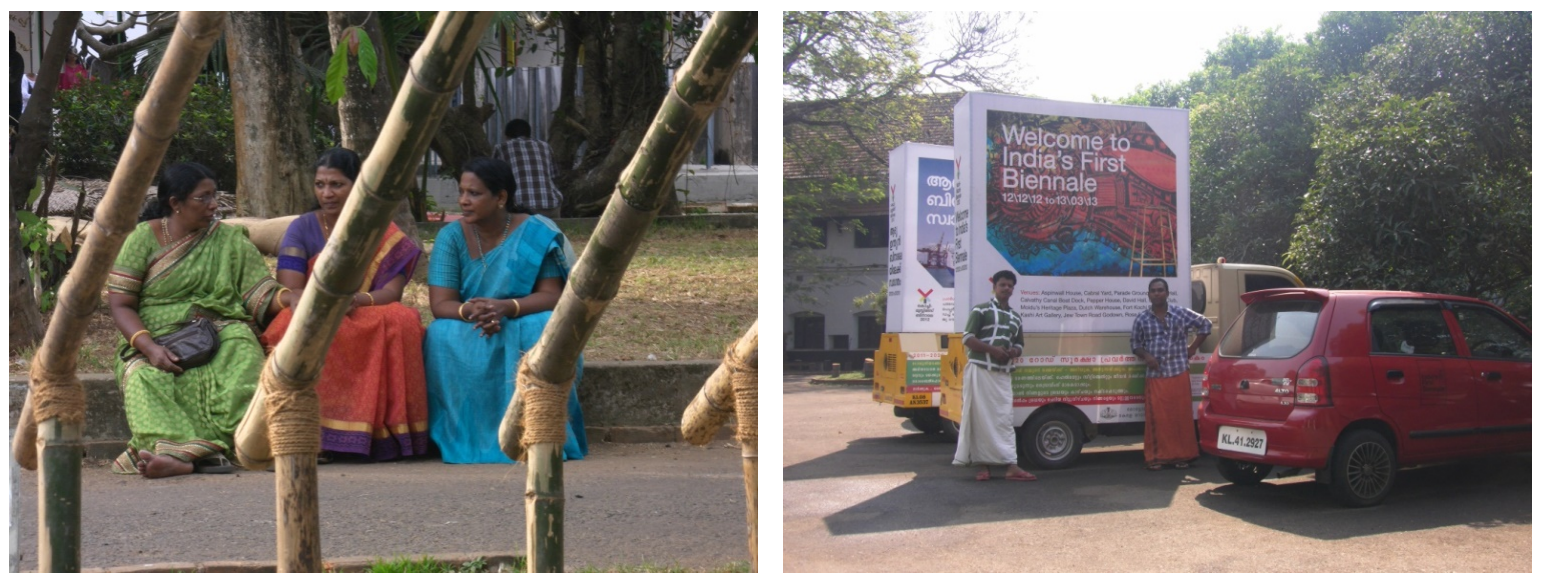

Robert E. D'Souza, Reader in Critical and Cultural Theory Within Winchester School of Art, writes of the Biennale:

The construction, let alone the launching, of exhibitions across citywide sites, was visibly challenging. The effect of this was not wholly detrimental to the event, lending a grassroots feel in the communal problem solving, which I could see still being played out well after the launch. It seemed apt in this deeply socialist state to see the visibility of the labor needed in the "production" of art, which, in other circumstances, might have been a less effective avant-garde gesture or performance but here seemed both honest and a welcome antidote to the selfconscious performance of reality.

While it was clear that some international visitors were perturbed by the unfinished nature of the biennale spaces and the lack of censure, it was also clear that this situation radically located this particular biennale as being uniquely Indian while acting as an antithetical gesture to the homogeneity and the clinical choreography of similar Western art events I have visited. What was also refreshingly apparent was the diversity of the audience: not just the usual suspects and VIPs of the international pack of art tourists, critics, curators, artists, and media that would normally be present, but a very democratic and largely local contingent that comprised local workers, schoolchildren, and a very general public. The influx of the art jet set is a manifestation of the politics of globalization, and when seen in Kerala brings to mind that "in The Communist Manifesto Marx and Engels argue that the bourgeoisie has created a new internationalism via the world market" (Harvey 1990: 99). Fortunately the lack of physical barriers or entry fee made for a more accessible event, while the reappointing of redundant 
historical spaces with many works responsive to the locality made visiting the biennale both an inclusive and a democratic proposition. ${ }^{10}$

This engagement with local politics and people flourished in ensuing Biennales. KMB20I4 curated by Jitish Kallat and entitled "Whorled Explorations" included History Now (a series of talks and seminars), an Artists's Cinema, Student's Biennale, Children's Biennale and a Program of events focusing on traditional art forms. The First Urban Space Dialogue in Kerala was organised by the Centre for Public Policy Research Centre for Urban Studies in partnership with Kochi Biennale Foundation where artists, architects and policy makers converged at Aspinwall. The Dialogue brainstormed ideas on Urban Spaces and the necessity of it in the state of Kerala. The panelists shared their experiences and vision of creating the right urban spaces to "enlighten the curiousness of the citizenry"."

KMB2016 curated by Sudarshan Shetty was titled "Forming in the pupil of an eye" It repeated its' extensive programming such as Student's Biennale, Cinema and Seminars, and extended the reach physically by installing at Kottapuram Fort, some $25 \mathrm{kms}$ from Fort Cochin and built by the Portuguese in 1523 and referred to popularly as Cranganore Fort.

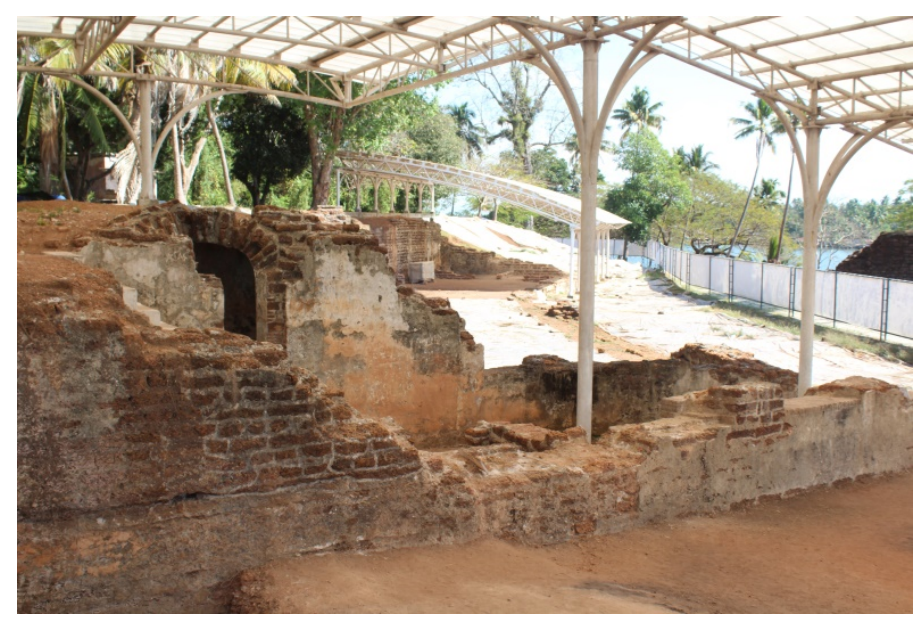

Our identities are shaped by the stories we hear and tell about ourselves over time. While certain aspects of identity are fixed and unchangeable, our social identity is formed in relationship to others. They are produced in our encounters with other people and can be understood as forms of "everyday performances" or "masks" that we wear differently depending on who we are with and what we want to present about ourselves. Spirit of Place (Genius Loci) refers to a unique, distinctive and cherished aspect of a place as much in the invisible weave of culture as it is in the tangible physical aspects of place: a new layer of ley lines, feng shui, leftover spaces ${ }^{12}$. This spirit reflects how a city functions in real time as people move through time and space. And so here I am, living, loving my liminal life. I work with/inhaibit various personae which act as filters for my past. They set up the instruments for my exploration and interrogation of identity. I weave notions of

\footnotetext{
${ }^{10}$ https://read.dukeupress.edu/cultural-politics/article/9/3/296/2593 I

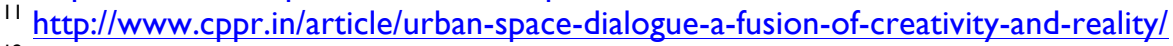

12 https://en.wikipedia.org/wiki/Spirit_of_place
}

I I 6 | The Journal of Public Space, 3(I), 2018 | ISSN 2206-9658

City Space Architecture / Queensland University of Technology / UN-Habitat 
Place and Identity into a series of insertions both performative and the residue of performance, and seek to engage with the local and in contrast with the "outsider".

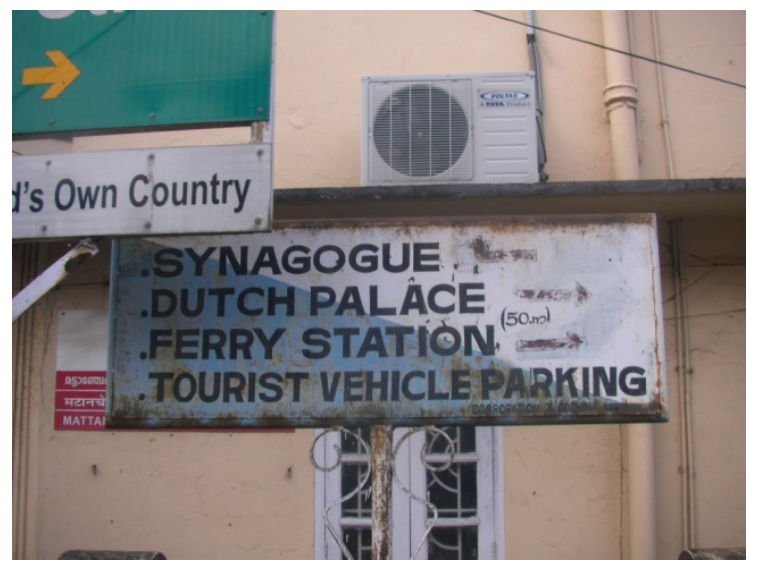

That outsider is ME. Di Ball. A large, old, Australian woman searching for her identity in this land.

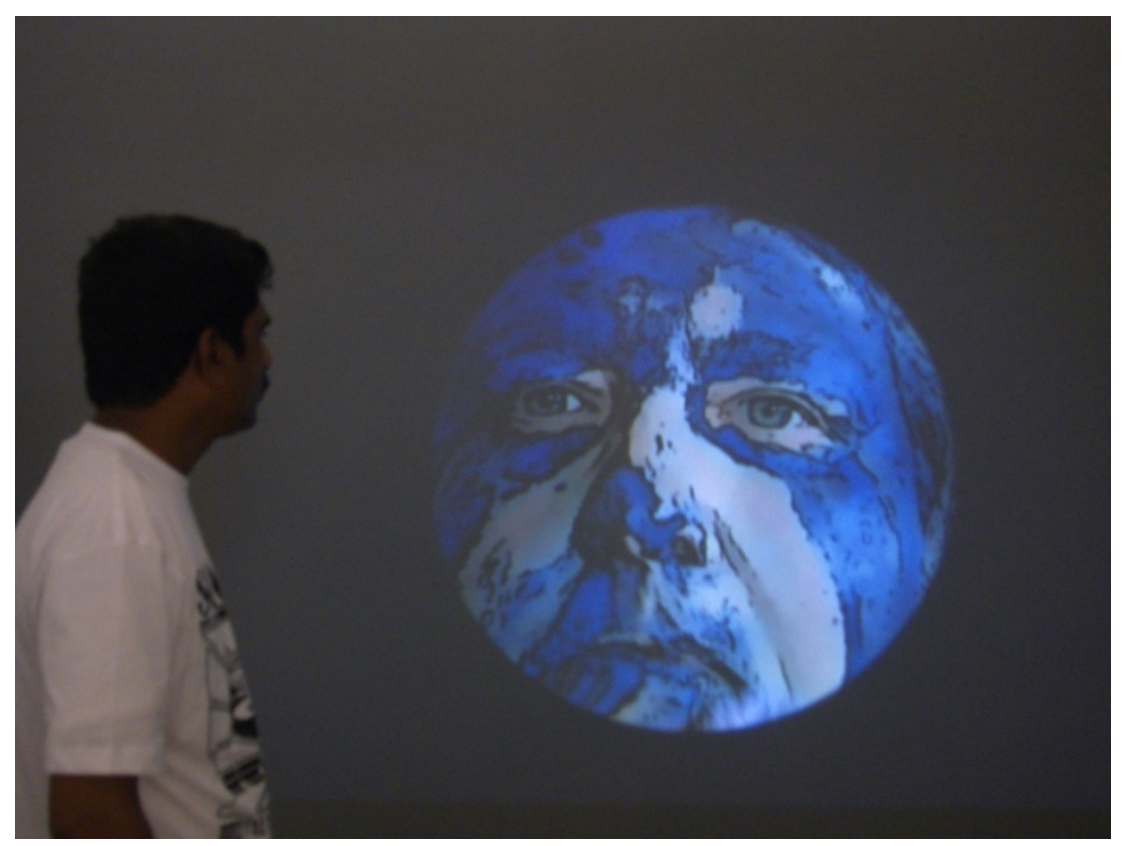

Di Ball (2012), binDi Ball is deeply superficial, installation view of video 


\section{I look at myself \\ And find no trace of identity \\ In this some supersensory radiance}

What is that unknown around which this unknown (self) rotates in perpetual motion? It's as if the expanse of memory and forgetting, down the ages and far away

Make up its atmosphere

And get accumulated in different forms of history.

The "l" takes shape in its midst in the course of countless years.

Joy and Sorrow, good and ill, anger and envy, devotion friendship love -

with these are constituted its material body.

These are the ingredients - they are rotated, collected, danced.

The truth of their being

I myself haven't understood.

Rabindranath Tagore (1938) Prashna (Question) Visra-Bharati Vol XII, p. I 35

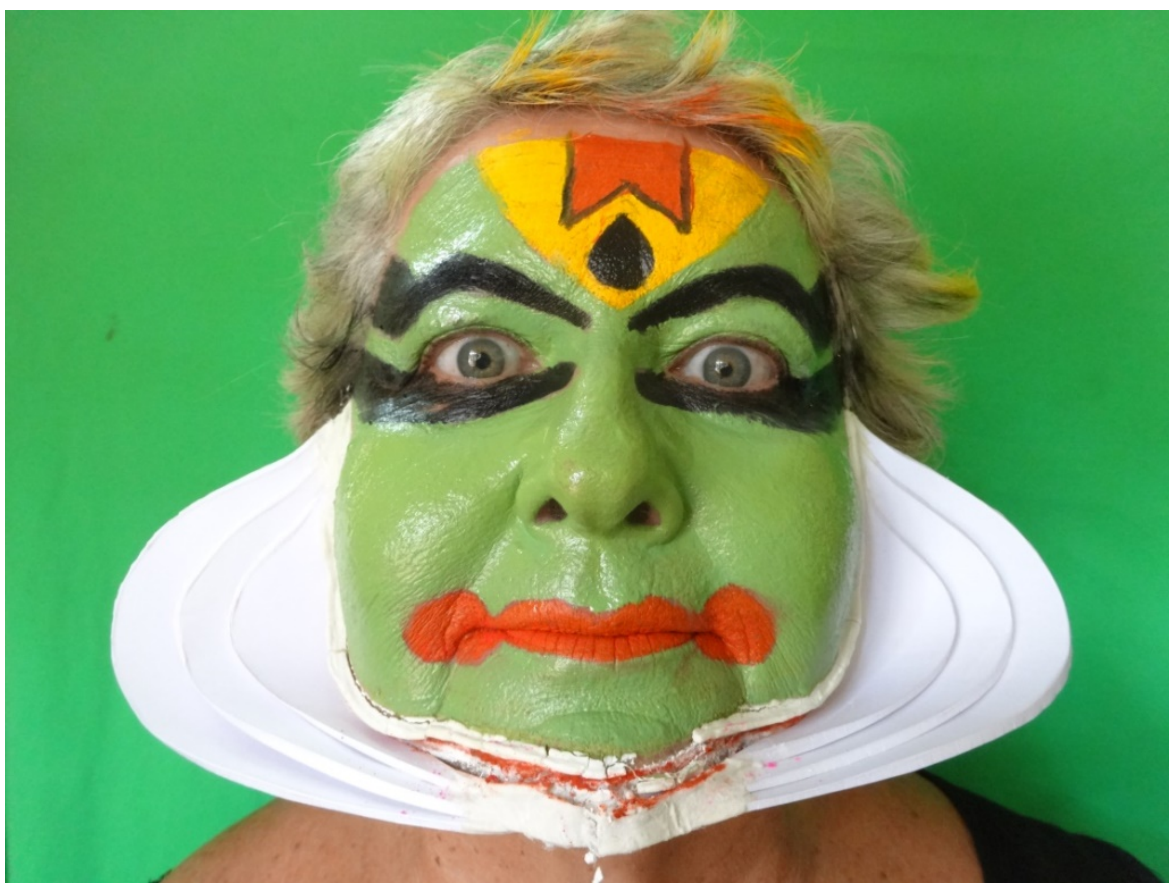

\section{To cite this article:}

Ball, D. (20I8). Postcards from the edge (of the Arabian Sea). Tales from the ballPark: this liminal life. The Journal of Public Space, 3(I), I09-I I8. DOI: I0.5204/jps.v3iI.322

This article has been accepted for publication in The Journal of Public Space. Please see the Editorial Policies under the 'About' section of the journal website for further information.

This work is licensed under a Creative Commons Attribution - Non Commercial 4.0

International License - https://creativecommons.org/licenses/by-nc/4.0/

I I 8 | The Journal of Public Space, 3(I), 20I8 | ISSN 2206-9658

City Space Architecture / Queensland University of Technology / UN-Habitat 